\title{
BRAF NP_004324.2:p.L597Q
}

National Cancer Institute

\section{Source}

National Cancer Institute. BRAF NP 004324.2:p.L597Q. NCI Thesaurus. Code C98330.

A change in the amino acid residue at position 597 in the serine/threonine protein kinase

B-raf protein where leucine has been replaced by glutamine. 